Vol 2 No 1 (2018) Page $118-123$

JURNAL OBSESI : JURNAL PENDIDIKAN ANAK USIA DINI

Research \& Learning in Early Childhood Education

https://obsesi.or.id/index.php/obsesi

\title{
Persepsi Mahasiswa PG-PAUD Universitas Muhammadiyah Ponorogo terhadap PAUD di Kabupaten Ponorogo
}

\section{Fadlillah}

Universitas Muhammadiyah Ponorogo

\begin{abstract}
ABSTRAK
Tujuan penelitian ini adalah (1) untuk mengetahui persepsi mahasiswa PGPAUD terhadap pendidikan anak usia dini di Kabupaten Ponorogo. (2) untuk mengetahui kendala-kendala pendidikan anak usia dini di Kabupaten Ponorogo berdasarkan persepsi mahasiswa PG-PAUD Universitas Muhammadiyah Ponorogo. Metode yang digunakan dalam penelitian ini adalah kualitatif deskriptif dengan melibatkan 30 mahasiswa. Pengumpulan data dilakukan dengan teknik wawancara. Wawancara dilakukan secara langsung kepada mahasiswa PGPAUD Universitas Muhammadiyah Ponorogo. Hasil penelitian ini yaitu 1) persepsi mahasiswa PGPAUD terhadap pelaksanaan pendidikan anak usia dini di Kabupaten Ponorogo secara umum belum berjalan dengan baik sesuai standar nasional pendidikan anak usia dini. 2) kendala-kendala pendidikan anak usia dini di Kabupaten Ponorogo yaitu a) terdapat sebagian guruguru PAUD yang belum S1 PGPAUD, kesejahteraan guru PAUD yang masih rendah, sarana dan prasarana belum memadai, serta mininya bantuan dari pemerintah, baik pusat maupun daerah.
\end{abstract}

Kata Kunci: Persepsi, pendidikan anak usia dini

\begin{abstract}
The purpose of this study were (1) to know the perception of PGPAUD students toward early childhood education in Ponorogo District. (2) to know the obstacles of early childhood education in Ponorogo Regency based on perception of PG-PAUD students Muhammadiyah University of Ponorogo. The method used in this research is qualitative descriptive involving 30 students. Data collection was done by interview technique. The interview was conducted directly to the students of PGPAUD Muhammadiyah University of Ponorogo. The results of this study are 1) PGPAUD student perception on the implementation of early childhood education in Ponorogo regency in general has not run well according to national standards of early childhood education. 2) the obstacles of early childhood education in Ponorogo District are a) there are some teachers of PAUD who have not S1 PGPAUD, the welfare of early childhood teachers are still low, facilities and infrastructure is not adequate, and mininya assistance from the government, both central and local.
\end{abstract}

Keyword : Perception, Early Childhood Education

@ Jurnal Obsesi Prodi PG-PAUD FIP UPTT 2018

$\triangle$ Corresponding author : M. Fadlillah

Address : Universitas Muhammadiyah Ponorogo

ISSN 2356-1327 (Media Cetak)

Email : fadly_ok@yahoo.co.id

ISSN 2549-8959 (Media Online)

Phone : 085726152529 


\section{PENDAHULUAN}

Pendidikan anak usia dini di Indonesia sudah mengalami perkembangan yang signifikan dari tahun ke tahun, tidak terkecuali di wilayah Kabupaten Ponorogo. Pemerintah melalui dinas pendidikan daerah telah mengeluarkan berbagai bentuk kebijakan dan bantuan dalam upaya menjalankan dan meningkatkan mutu pendidikan anak usia dini di Indonesia. Namun demikian, tidak semua lembaga pendidikan anak usia dini mendapat bantuan yang maksimal, sehingga pelaksanaan pendidikan anak usia dini pun tidak berjalan sesuai dengan semestinya.

Pendidikan anak usia dini merupakan pendidikan yang ditunjukan kepada anak yang berada dalam rentang usia $0-8$ tahun (Morrison, 2012:4). Pendidikan ini dimaksudkan untuk mengembangkan berbagai potensi yang dimiliki anak, baik jasmani maupun rohani, supaya dapat berkembang dengan optimal. Dalam Undang- Undang Nomor 20 Tahun 2003 tentang Sistem Pendidikan Nasional disebutkan bahwa Pendidikan Anak Usia Dini adalah suatu upaya pembinaan yang ditujukan kepada anak sejak lahir sampai dengan usia enam tahun yang dilakukan melalui pemberian rangsangan pendidikan untuk membantu pertumbuhan dan perkembangan jasmani dan rohani agar anak memiliki kesiapan dalam memasuki pendidikan lebih lanjut.

Pelaksanaan pendidikan anak usia dini di Kabupaten Ponorogo sangat berbeda dengan daerah-daerah yang lain. Mulai dari pengelolaan lembaga sampai pada bentuk pembelajaran. Misalnya dalam pembelajarannya mayoritas masih klasikal, pembiayaan masih sangat minim, sarana dan prasarana kurang memadai, lebih-lebih kesejahteraan guru masih jauh dari kata cukup. Tentu kondisi ini menjadi persoalan tersendiri dalam pelaksanaan pendidikan anak usia dini di Kabupaten Ponorogo .Ada beberapa faktor yang mempengaharuhi perbedaan tersebut, baik secara internal maupun eksternal. Dari internal, misalnya dilihat dari sumber daya manusianya maupun sarana dan prasarananya, sedangkan dari eksternal dapat berupa kepercayaan dari masyarakat dan bentuk pembiayaannya.

Permasalahan teresebut sudah seharusnya diketahui dan dipahami oleh mahasiswa prodi Pendidi Guru Pendidikan Aanak Usia Dini (PG-PAUD) Universitas Muhammadiyah Ponorogo. Sebab mereka merupakan calon pendidik yang akan berkecipung atau terjun langsung dalam dunia pendidikan anak usia dini di Kabupaten Ponorogo. Dalam rangka mengetahui seberapa jauh pengetahuan dan pemahaman mahasiswa terhadap pendidikan anak usia dini di Kabupaten Ponorogo, maka perlu digali berbagai persepsi mahasiswa terkait persolan tersebut. Dengan persepsi tersebut setidaknya mahasiswa PG-PAUD Universitas Muhammadiyah Ponorogo dapat ikut berkontribusi atau memberikan solusi terhadap persoalan-persoalan pendidikan anak usia dini di Kabupaten Ponorogo. Dengan kata lain, mereka mempunyai tanggungjawab moril dalam meningkatkan kualitas pendidikan anak usia dini di Kabupaten Ponorogo.

\section{Definisi Persepsi PAUD}

Dalam Kamus Besar Bahasa Indonesia persepsi dimaknai sebagai tanggapan (penerimaan) langsung dari sesuatu atau proses seseorang mengetahui beberapa hal melalui panca indranya. Istilah persepsi sendiri berasal dari bahasa latin yaitu perceptio yang memiliki makna tindakan menyusun, mengenali, dan menafsirkan informasi sensoris guna memberikan gambaran dan pemahaman tentang lingkungan (http://id.wikipedia.org).

Pengertian tersebut memeberikan penjelasan bahwa persepsi merupakan suatu proses pengematan seseorang terhadap lingkungan dengan menggunakan indranya sehingga mampu menghasilkan sebuah tanggapan atau gambaran mengenai lingkungan tersebut.

Menurut Slameto (2010:102) persepsi adalah proses yang menyangkut masuknya pesan atau informasi kedalam otak manusia, melalui persepsi manusia terus menerus mengadakan hubungan dengan lingkungannya. Hubungan ini dilakukan lewat inderanya, yaitu indera pengelihat, pendengar, peraba, perasa, dan pencium. Pendapat lain menyebutkan bahwa persepsi adalah proses individu dalam menginterprestasikan, mengorganisasikan dan memberi makna terhadap stimulus yang berasal dari lingkungan di mana individu itu berada yang merupakan hasil dari proses belajar dan pengalaman. Kedua pengertian tersebut memiliki kesamaan yaitu persepsi diperoleh melalui pengelaman indra seseorang dari lingkungannya, kemudian menghasilkan sebua tanggapan atau pengetahuan mengenail lingkungan tersebut.

Dalam kaitannya dengan pendidikan anak usia dini, persepsi di sini dimaksudkan untuk memperoleh tanggapan tentang pelaksanaan pendidikan anak usia dini, khususnya di Kabupaten Ponorogo. Persepsi ini digali dari mahasiswa Program Studi Pendidikan Guru Pendidikan Anak Usia Dini (PG-PAUD). 
Harapannya dengan peresepsi ini diperoleh gambaran tentang pendidikan anak usia dini di Kabupaten Ponorogo.

Menurut Walgito (1989:54) terdapat tiga syarat terjadi sebuah persepsi, yaitu: (1) adanya objek yang dipersepsi, (2) adanya alat indra atau reseptor, dan (3) adanya perhatian. Ketiga syarat tersebut saling berpengaruh satu sama lain. Artinya, persepsi akan menghasilkan sebuah tanggapan atau gambaran manakala syaratsyarat tersebut dialami langsung oleh seseorang.

Adapun faktor-faktor yang mempengaruhi persepsi ada dua, yaitu faktor internal dan faktor eksternal. Faktor internal berupa perasaan, sikap dan kepribadian individu, prasangka, keinginan atau harapan, perhatian (fokus), proses belajar, keadaan fisik, gangguan kejiwaan, nilai dan kebutuhan juga minat, dan motivasi. Sedangkan faktor eksternal berupa latar belakang keluarga, informasi yang diperoleh, pengetahuan dan kebutuhan sekitar, intensitas, ukuran, keberlawanan, pengulangan gerak, hal-hal baru dan familiar atau ketidak asingan suatu objek (Miftah Toha, 2003:154).

Di samping itu, menurut Walgito (2004:70) terdapat tiga faktor utama yang mempengaruhi persepsi seseorang, di antaranya:

a. Objek yang dipersepsi; Objek menimbulkan stimulus yang mengenai alat indera atau reseptor. Stimulus dapat datang dari luar individu yang mempersepsi, tetapi juga dapat datang dari dalam diri individu yang bersangkutan yang langsung mengenai syaraf penerima yang bekerja sebagai reseptor.

b. Alat indra; syaraf dan susunan syaraf alat indera atau reseptor merupakan alat untuk menerima stimulus, di samping itu juga harus ada syaraf sensoris sebagai alat untuk meneruskan stimulus yang diterima reseptor ke pusat susunan syaraf, yaitu otak sebagai pusat kesadaran. Sebagai alat untuk mengadakan respon diperlukan motoris yang dapat membentuk persepsi seseorang.

c. Perhatian; untuk menyadari atau dalam mengadakan persepsi diperlukan adanya perhatian, yaitu merupakan langkah utama sebagai suatu persiapan dalam rangka mengadakan persepsi. Perhatian merupakan pemusatan atau konsentrasi dari seluruh aktivitas individu yang ditujukan kepada sesuatu sekumpulan objek.
Dari berbagai uraian tersebut dapat dipahami bahwa persepsi pendidikan anak usia dini dimaksudkan untuk mendapatkan gambaran mengenai kondisi pendidikan anak usia dini dilihat dari sudut pandang mahasiswa. Pandangan mahasiswa mengenai pendidikan anak usia dini ini dapat dijadikan tolak ukur kemampuan mahasiswa dalam menyikapi berbagai kondisi dan isu perkembangan pendidikan anak usia dini.

\section{METODE PENELITIAN}

Penelitian ini merupakan penelitian kualitatif deskriptif dengan melibatkan mahasiswa PGPAUD Universitas Muhammadiyah Ponorogo. Adapun yang menjadi subjek penelitian yaitu mahasiswa PGPAUD. Jumlah mahasiswa yang terlibat sebanyak 30 orang, terdiri dari semester 4 dan semester 5. Pengumpulan data dilakukan melalui wawancara secara langsung kepada mahasiswa. Pertanyaan-pertanyaan yang diberikan sejumlah sepuluh pertanyaan yang berkaitan dengan pelaksanaan pendidikan anak usia dini di Kabupaten Ponorogo. Melalui wawancara ini diperoleh gambaran mengenai pandangan mahasiswa tentang kondisi pelaksanaan pendidikan anak usia dini di Kabupaten Ponorogo.

\section{PEMBAHASAN}

\section{Pelaksanaan Pendidikan Anak Usia Dini di Kabupaten Ponorogo}

Pendidikan anak usia dini merupakan pendidikan yang diberikan kepada anak yang berada pada rentang usia $0-6$ tahun. Menurut UU No. 20 tahun 2003 tentang Sistem Pendidikan Nasional disebutkan bahwa pendidikan anak usia dini ialah suatu upaya pembinaan yang ditujukan kepada anak sejak lahir sampai dengan usia enam tahun yang dilakukan melalui pemberian rangsangan pendidikan untuk membantu pertumbuhan dan perkembangan jasmani dan rohani agar anak memiliki kesiapan dalam memasuki pendidikan lebih lanjut. Definisi tersebut juga tercantum dalam Permendikbud No. 137 Tahun 2014 tentang Standar Nasional Pendidikan Anak Usia Dini.

Berkaitan dengan definisi pendidikan anak usia dini ini mahasiswa pendidikan guru pendidikan anak usia dini Universitas Muhammadiyah Ponorogo mengartikannya secara beragam. Sebagaian besar mahasiswa mendefinisikan seperti yang tertuang dalam Undang-Undang Sistem Pendidikan Nasional tahun 2003. Sebagian yang lain mendefinisikan dengan konteks yang berbeda dan mengaitkannya dengan kondisi perkembangan anak. Terdapat lima belas mahasiswa yang mendifinisikan pendidikan anak usia dini sebagai pendidikan yang ditujukan 
kepada anak usia $0-6$ tahun untuk mempersiapkan anak menuju pendidikan selanjutnya. Definisi pendidikan anak usia dini ini dijelaskan secara sederhana dan hanya ditekankan pada anak usia 0 - 6 tahun serta dimaksudkan untuk mempersipkan anak memasuki pendidikan lebih lanjut.

Pengertian lebih luas dijelaskan oleh sepuluh mahasiswa yang lain. Menurut mereka pendidikan anak usia dini ialah suatu upaya pembinaan yang ditujukan bagi anak sejak lahir hingga 6 tahun yang dilakukan untuk pemberian rangsangan pendidikan untuk membantu pertumbuhan dan perkembangan jasmani dan rohani anak supaya siap memasuki pendidikan selanjutnya. Definisi ini jika dibandingkan yang pertama jauh lebih lengkap. Di mana pendidikan dimaknai sebagai usaha pembinaan untuk anak usia $0-6$ tahun dalam rangka memaksimalkan pertumbuhan dan perkembangan anak supaya dapat memasuki pendidikan lebih lanjut dengan maksimal.

Dari beberapa persepsi mahasiswa pendidikan guru pendidikan anak usia dini Universitas Muhammadiyah Ponorogo tersebut, dapat dipahami bahwa pengertian pendidikan anak usia dini paling tidak mencakup tiga hal, di antaranya: (1) pendidikan atau upaya pembinaan ditujukan kepada anak usia 0 - 6 tahun, (2) pendidikan dimaksudkan untuk menstimulasi pertumbuhan dan perkembangan anak, baik jasmani maupun rohani, dan (3) pendidikan dilakukan dalam rangka mempersiapkan anak memasuki pendidikan lebih lanjut.

Berkaitan dengan pelaksanaan pendidikan anak usia dini di Kabupaten Ponorogo mahasiswa pendidikan guru pendidikan anak usia dini Universitas Muhammadiyah Ponorogo mempunyai persepsi yang beragam. Untuk mengetahui pelaksanaan pendidikan anak usia dini ini dapat dilihat melalui beberapa unsur, di antaranya:

\section{a. Kurikulum}

Berkaitan dengan kurikulum yang digunakan dalam pendidikan anak usia dini secara mayoritas mahasiswa pendidikan guru pendidikan anak usia dini berpendapat bahwa kurikulum yang diterapkan dalam pembejaran sebagian besar lembaga PAUD masih menggunakan kurikulum tingkat satuan pendidikan. Meskipun sudah ada yang menerapkan Kurikulum 2013, namun jumlahnya masih sangat terbatas.
Kondisi ini menggambarkan bahwa pendidikan anak usia dini di Kabupaten Ponorogo masih harus ditingkatkan kualitasnya serta perlu mendapatkan perhatian khusus dari pemerintah daerah. Hal ini dimaksudkan supaya pendidikan anak usia dini di Kabupaten Ponorogo semakin meningkat kualitasnya, sehingga dapat bersaing dengan daerah-daerah yang lain.

b. Model pembelajaran

Model pembelajaran merupakan suatu bentuk langkah-langkah pembelajaran yang digunakan dalam memperlancar aktivitas pembelajaran. Menurut persepsi sebagian besar mahasiswa pendidikan guru pendidikan anak usia dini model pembelajaran yang digunakan dalam pendidikan anak usia dini di Kabupaten Ponorogo secara umum masih menggunakan model klasikal. Dalam konteksi ini aktivitas pembelajaran masih didominasi oleh guru, sedangkan anak didik cenderung mengikuti apa yang diperintahkan oleh guru. Kondisi ini menjadikan anak kurang bereksplorasi dalam mengembangkan berbagai kemampuannya.

Pada era sekarang ini, seharusnya model pembelajaran klasikal sudah ditinggalkan dan berganti menggunakan model pembelajaran yang lainnya. Menurut Direktorat Pendidikan Anak Usia Dini model pembelajaran yang berkembang dan banyak diaplikasikan dalam pendidikan anak usia dini ialah model pembelajaran sentra (Depdiknas, 2015:12). Model pembalajaran sentra adalah model pembelajaran yang dalam proses pembelajarannya dilakukan di dalam "lingkaran" (circle times) dan sentra bermain. Lingkaran yaitu pendidik duduk bersama anak duduk melingkar untuk memberikan pijakan kepada anak, baik sebelum maupun sesudah bermain. Sentra bermain ialah zona bermain anak yang dilengkap dengan seperangkat alat bermain.

Pembelajaran dengan model sentra ini dianggap sebagai model yang sangat tepat untuk pendidikan anak usia dini, sebab anak dapat terlibat secara aktif dalam pembelajaran. Di mana peran guru hanya sebagai fasilitator dan pembimbing anak didik. Melalui model sentra ini anak-anak dapat bereksplorasi sesuai dengan imajinasi anak masing-masing.

Oleh karena itu, sebaiknya pendidikan anak usia dini di Kabupaten Ponorogo mulai berubah menggunakan model sentra dalam kegiatan pembelajarannya. Selain untuk memberikan kesempatan anak untuk bereksplorasi, juga untuk mempermudah guru dalam megajar. Melalui model pembelajaran ini guru hanya berperan sebagai fasilitator, sehingga dominasi guru menjadi berkurang. Dalam model pembelajaran ini yang dituntut lebih aktif adalah anak didik. 


\section{c. Sarana dan prasarana}

Berkaitan dengan sarana dan prasarana ini, menurut sebagian besar mahasiswa pendidikan guru pendidikan anak usia dini universitas muhammadiyah ponorogo berpendapat bahwa sarana dan prasarana pendidikan anak usia dini di Kabupaten Ponorogo masih jauh yang diharapkan, karena belum sesuai dengan kebutuhan dan yang seharusnya. Keterbatasan dan belum sesuainya sarana dan prasarana ini dapat dilihat melalui kondisi bangunan dan kelas yang belum layak dan belum sesuai dengan standar yang diterapkan oleh pemerintah. Di samping itu, sarana-sarana penunjang pembelajaran, seperti media dan alat permainainan edukatif masih sangat terbatas jumlahnya. Hal ini dikarenakan kemampuan finansial lembaga masih terbatas, sehingga kurang mampu membeli berbagai sarana pembelajaran tersebut. Meskipun sudah ada bantuan dari pemerintah pusat maupun pemerintah daerah setempat, akan tetapi bantuan tersebut dirasa belum cukup untuk memenuhi berbagai kebutuhan pendidikan anak usia dini. Namun demikian, guru maupun lembaga tetap berusaha memenuhi berbagai kekurangan yang ada, meskipun dilakukan secara bertahap disesuikan dengan skala prioritas.

Terlepas dari berbagai kekurangan dan keterbatasan pendidikan anak usia dini di Kabupaten Ponorogo tersebut, sebagaian besar mahasiswa pendidikan guru pendidikan anak usia dini universitas muhammadiyah ponorogo meyakini bahwa pelaksanaan pendidikan anak usia dini di Kabupaten Ponorogo sudah berjalan dengan baik. Paling tidak ada 19 (sembilan belas) mahasiswa yang berpendapat demikian. Mereka beralasan bahwa pendidikan anak usia dini di Kabupaten Ponorogo sudah terprogram dengan baik. Di samping itu, pendidikan anak usia dini di Kapupaten Ponorogo secara umum telah mengacu dan mengikuti ketentuan yang ada dalam Permendikbud No. 137 Tahun 2014 tentang Standar Nasional Pendidikan Anak Usia Dini. selain itu, keberlangsungan pendidikan anak usia dini di Kabupaten Ponorogo juga didukung oleh berbagai organisasi PAUD, seperti Himpaudi, IGTKI, IGRA dan IGABA, sehingga pelaksanaan pendidikannya lebih terarah dan dapat dipantau perkembangannya.
Adapun jumlah mahasiswa yang menyatakan bahwa pendidikan anak usia dini di Kabupaten Ponorogo belum berjalan dengan baik yaitu 9 (sembilan) mahasiswa. Mereka beralasan bahwa belum maksimalnya pendidikan anak usia dini di Kabupaten Ponorogo didasari atas beberapa faktor, di antaranya: banyak lembaga PAUD yang belum menerapkan Kurikulum 2013, model dan metode pembelajaran yang masih klasikal, terdapat beberapa guru yang belum memenuhi kualifikasi akademik, serta sarana dan prasarana yang masih terbatas. Berdasarkan berbagai kekurang tersebut, mereka berasumsi bahwa pendidikan anak usia dini di Kabupaten Ponorogo belum berjalan dengan ideal dan masih harus kerja keras untuk meningkatkan kualitasnya.

\section{Kendala-Kendala Pendidikan Anak Usia Dini di Kabupaten Ponorogo}

Dalam pelaksanaan pendidikan anak usia dini di Kabupaten Ponorogo masih terdapat kendala-kendala yang perlu dihadapi dan dicarikan solusinya secara bersama-sama. Menurut persepsi mahasiswa pendidikan guru pendidikan anak usia dini Universitas Muhammadiyah Ponorogo terdapat beberapa kendala pendidikan anak usia dini di Kabupaten Ponorogo, di antaranya:

a. Masih terdapat guru-guru PAUD yang belum memenuhi kualifikasi akademik. Sebagian besar guru PAUD di Kabupaten Ponorogo yang masih lulusan SMA sederajat. Selain itu, ada beberapa guru PAUD yang ijazah sarjana tidak sesuai dengan bidang pendidikan anak usia dini. Kondisi ini sedikit menghambat dalam peningkatan kualitas pendidikan anak usia dini.

b. Sarana dan prasarana masih terbatas dan belum memenuhi standar ideal pendidikan anak usia dini.

c. Rata-rata lembaga PAUD di Kabupaten Ponorogo dikelola oleh swasta, sehingga pembiayaan operasional sehari-hari masih sangat terbatas. Di samping itu, bantuan dari pemerintah, baik pusat maupun daerah juga terbatas. Kondisi ini menjadikan sekolah harus bekerja ekstra dalam memenuhi berbagai kebutuhan maupun sarana pembelajaran. Terutama bagi lembaga- lembaga PAUD yang ada di pedesaan.

d. Kesejahteraan guru PAUD di Kabupaten Ponorogo masih relatif kecil, sehingga secara tidak langsung berpengaruh terhadap layanan dan proses pembelajaran pendidikan anak usia dini. Selain itu, kondisi tersebut menjadikan guru-guru PAUD di Kabupaten Ponorogo tidak dapat mengembangkan kompetensinya dengan maksimal. 


\section{KESIMPULAN}

Persepsi mahasiswa Pendidikan Guru Pendidikan Anak Usia Dini (PGPAUD) Universitas Muhammadiyah Ponorogo terhadap pendidikan anak usia dini di Kabupaten Ponorogo sangat beragam, terutama dalam mendefinisikan pendidikan anak usia dini. Nmun secara keseluruhan mahasiswa sudah dapat mendefinisikan pendidikan anak usia dini dengan baik. Berkaitan dengan pemahaman mahasiswa terhadap pelaksanaan pembelajaran anak usia dini dapat dipahami bahwa pendidikan anak usia dini di Kabupaten Ponorogo sudah berjalan dengan baik, meskipun masih ada beberapa kekurangan. Adapun beberapa kendalakendala dalam pelaksanaan pendidikan anak usia dini di Kabupaten Ponorogo berdasarkan persepsi mahasiswa PGPAUD Universitas Muhammadiyah Ponorogo, antara lain: sebagian guru belum memenuhi kualifikasi akademik D IV / S1 PAUD / S1 Psikologi, sarana dan prasarana yang kurang memadai, masih terbatasnya bantuan dari pemerintah maupun swasta, dan rendahnya kesejahteraan guru.

\section{DAFTAR PUSTAKA}

Arikunto, S. 2002. Prosedur Penelitian; Suatu Pendekatan Praktek. Jakarta: Rineka Cipta.

Depdikanas. 2015. Pedoman Perencanaan Pengelolaan Kelas Pendidikan Anak Usia Dini. Kemendikbud.

Depdiknas. 2014. Permendikbud No. 137 Tahun 2014 tentang Standar Nasional Pendidikan Anak Usia Dini.

Depdiknas. 2014. Permendikbud No. 146 Tahun

2014 tentang Kurikulum 2013 PAUD.

Hasmalena, H., Rantina, M., \& Rukiyah, R. (2018). Pengaruh Penggunaan Multimedia terhadap Pemahaman Konsep pada Mata Kuliah Pengembangan Kognitif dan Kreatifitas Anak Usia Dini di UNSRI Palembang. Jurnal Obsesi : Journal of Early Childhood Education, 2(1), 82-90. doi:10.31004/obsesi.v2i1.789
Morrison, G. S. 2012. Dasar-Dasar Pendidikan Anak Usia Dini. Edisi Kelima. (Penerjemah Suci Romadhona dan Apri Widiastuti). Jakarta: Indeks. (Edisi asli diterbitkan tahun 2008 oleh Pearson Education, Inc).

Republik Indonesia. 2013. Undang-Undang No. 20 Tahun 2003 tentang Sistem Pendidikan Nasional.

Slameto. 2010. Belajar dan Faktor-Faktor yang Mempengaruhinya. Jakarta: Rineka Cipta.

Sudijono, Anas. 2005. Pengantar Evaluasi Pendidikan. Jakarta: Rajawali Press.

Sugiyono. 2011. Metode Penelitian Kuantitatif, Kualitatif, dan $R \& D$. Bandung: Alfabeta.

Toha, M. 2003. Perilaku Organisasi Konsep Dasar dan Aplikasinya. Jakarta: Grafindo Persada.

Walgito, Bimo. 2004. Pengantar Psikologi Umum. Surabaya: Bina Ilmu. 